\title{
MANUFACTURE AND CHARACTERIZATION OF AA6061 ALUMINUM ALLOY METAL MATRIX COMPOSITES WITH CERAMIC PARTICULATE REINFORCEMENT
}

\author{
Diogo Monteiro do Nascimento*, Moisés Euclides da Silva Junior*, José Endreo Baracho da \\ Costa*, Sandra Torres Zarzar*, Max Breno Bezerra Muniz**, Oscar Olimpio de Araujo Filho* \\ ${ }^{*}$ Mechanical Engineering Department, Federal University of Pernambuco, Cidade Universitária, Recife 50740-540 \\ ${ }^{* *}$ Mechanical Engineering Department, University Center Estácio do Recife, Prado, Recife 52171-011
}

\section{ARTICLE INFO}

\section{Article History:}

Received $26^{\text {th }}$ February, 2021

Received in revised form $13^{\text {th }}$ March, 2021

Accepted $11^{\text {th }}$ April, 2021

Published online $22^{\text {th }}$ May, 2021

\section{Key Words:}

AA6061, ceramics reinforcements,

Composites, hot extrusion,

Powder metallurgy.

*Corresponding author:

Disogo Monteiro do Nascimento

\begin{abstract}
The work's main objective was the manufacture of an AA6061 aluminum metal matrix composite reinforced with ceramics reinforcements of: aluminum oxide, silicon carbide, aluminum nitride and silicon nitride, through the powder metallurgy technique. The powders were subjected to high energy milling in a SPEX type vibrating mill. Thereafter, a cold uniaxial compactation was made and then the compacts were hot extruded. The powders were subjected to characterization using X-ray diffraction and laser diffraction granulometry. The extruded were characterized by scanning electron microscopy, energy dispersive spectroscopy and had their microhardness evaluated. The characterization showed: the reinforcements' addition in the matrix contributed to an acceleration of powders' grinding; the reinforced samples had a higher microhardness than the unreinforced; it was observed that greater milling times and reinforcement's addition increased the composites' microhardness.
\end{abstract}

Copyright $@ 2021$, Diogo Monteiro do Nascimento et al., 2021. This is an open access article distributed under the Creative Commons Attribution License, which permits unrestricted use, distribution, and reproduction in any medium, provided the original work is properly cited.

Citation: Diogo Monteiro do Nascimento, Moisés Euclides da Silva Junior, José Endreo Baracho da Costa, Sandra Torres Zarzar, Max Breno Bezerra Muniz, Oscar Olimpio de Araujo Filho, 2021. "Manufacture and characterization of aa6061 aluminum alloy metal matrix composites with ceramic particulate reinforcement "International Journal of Development Research, 11, (05), 46875-46883.

\section{INTRODUCTION}

Whit technological advances in the industrial field and materials science, composite materials have been increasingly studied, developed and employed in various activities (construction, aeronautics, automotive industry, among others). The focus on this type of material is large as composites can be manufactured to have specific and unusual properties. Although it is a material that has been used by man for many years, it was recognized as a distinct class of materials in the second half of the 20th century (Callister, 2010). Composites are a type of materials that are composed of more than one material, often very dissimilar, they are also manufactured by unconventional techniques (Callister, 2010). In the early 20th century, modern powder metallurgy (MP) was then used to manufacture tungsten carbides. However, during World War II there was an increase in the demand for techniques for the manufacture of composite materials and after this period the MP was developing to a process that today combines precision, speed and economy (Upadhyaya, 2002). In this respect, MP has become more widely used to manufacture materials that are very difficult or nearly impossible to produce by conventional forming, casting and machining techniques (Callister, 2010). MP is capable to produce composites with metallic, ceramic and polymeric matrix (Callister, 2010; Araujo Filho, 2016). Among the metals used as matrix in the composition of metal matrix composites (MMC), aluminum alloys are the second most used, behind only iron. Aluminum alloys are widely used in industry due to their properties: low specific weight, low density, ductility, good thermal and electrical conductivity, corrosion resistance (Kumar, 2018). Among the aluminum matrix composites (AMC) stand out the AA6061 alloy composites, since this alloy has higher strength and hardness being applied in structural elements and in the automotive industry (Barbosa, 2014). MMCs are usually reinforced with a ceramic phase, such as aluminum or alumina oxide $\left(\mathrm{Al}_{2} \mathrm{O}_{3}\right)$, silicon carbide $(\mathrm{SiC})$, aluminum nitride $(\mathrm{AlN})$ and silicon nitride $\left(\mathrm{Si}_{3} \mathrm{~N}_{4}\right)$. Alumina is widely used because it is a material that is obtained in the aluminum production process. Moreover the cost / benefit of this material is attractive, allied to the good properties such as hardness, abrasion resistance and chemical inertia (Campos, 2016). Silicon carbide becomes attractive due to its high hardness, thermal conductivity, chemical stability and semiconductor properties (Da Silva, 2014). Aluminum nitride is indicated as reinforcement in aluminum alloys due to its good coefficient of thermal expansion, good thermal stability, high strength and good dispersion in the aluminum matrix (Kumar, 2018). Silicon nitride is used as reinforcement due to its low coefficient of thermal expansion, hardness, mechanical strength and good corrosion resistance at high 
temperatures, and is well used in the aerospace industry (Baldacim, 2000). Therefore, this work is dedicated to the manufacture AMCs from AA6061 alloy reinforced with ceramic particulate of: $\mathrm{Al}_{2} \mathrm{O}_{3}$, $\mathrm{SiC}, \mathrm{AlN}$ and $\mathrm{Si}_{3} \mathrm{~N}_{4}$. To study the effects of the PM process on the fabrication of these composites, as well as the influence of reinforcement addition on the structure and microhardness of extruded samples.

\section{RELATED WORKS}

Due to the wide application of AA6061 alloys, this alloy is found in several areas. In aerospace industry it is possible to find AA6061 alloy composites, reinforced with ceramic particulate, applied as protection against lightning strikes. They are widely applied in these components, since aluminum has good electrical conductivity and the current produced by the lightning flows though the surface of the structure has less resistance, thus preventing damage to the aircraft from occurring due to the poor conduction of the electrical current Combined with good electrical conduction, AMCs still have good abrasion resistance and a high strength to weight ratio (Budumuru, 2021). Another industry that increased the use of aluminum alloy composites was the automotive industry. Aluminum alloys, such as AA6061, have been used to replace gray cast iron in the manufacture of brake rotors, pistons and engine blocks. AMCs are being used to manufacture parts that need wear resistance. Thus, ceramic reinforcements are a good option to be mixed with the aluminum matrix and thus promote increased wear resistance.This increase in wear resistance is directly related to the increase in hardness that the ceramic particulate promotes. In their studies Kumar M. et al. (2017) made use of an Al6061 / alumina / graphite / redmud alloy for use in the manufacture of brake rotors and proved that insertion of the ceramic reinforcement into the aluminum matrix promoted an improvement in the abrasion resistance of the material.

\section{MATERIALS AND METHODS}

The composites have AA6061 alloy as matrix, composition presented in Table 1, and the ceramic powders used as reinforcement were: alumina $\left(\mathrm{Al}_{2} \mathrm{O}_{3}\right)$, silicon carbide $(\mathrm{SiC})$, aluminum nitride $(\mathrm{AlN})$ and silicon nitride $\left(\mathrm{Si}_{3} \mathrm{~N}_{4}\right)$. The compositions of the composites and the time of high energy ball milling (HEBM) used in each sample are shown in Table 2. Stearic acid was used as process controller agent (PCA), it was used $2 \%$ fraction of the powder mass to be processed.

Table 1. Composition of AA6061 alloy

\begin{tabular}{ccccccccc}
\hline \multicolumn{10}{c}{$\mathrm{wt}^{\%} \%$} \\
$\mathrm{Si}$ & $\mathrm{Fe}$ & $\mathrm{Cu}$ & $\mathrm{Mn}$ & $\mathrm{Mg}$ & $\mathrm{Cr}$ & $\mathrm{Zn}$ & $\mathrm{Ti}$ & $\mathrm{Al}$ \\
0,8 & 0,7 & 0,4 & 0,15 & 1,2 & 0,35 & 0,25 & 0,15 & 96 \\
\hline
\end{tabular}

Table 2. Composition and nomenclature of samples

\begin{tabular}{cccc}
\hline Samples & Composition & Nomenclature & Milling Time \\
\hline 1 & $\mathrm{AA} 6061$ & $\mathrm{AA} 0$ & $0 \mathrm{~h}$ \\
2 & $\mathrm{AA} 6061$ & $\mathrm{AA} 2$ & $2 \mathrm{~h}$ \\
3 & $\mathrm{AA} 6061+10 \% \mathrm{Al}_{2} \mathrm{O}_{3}$ & $10 \mathrm{Al} 2 \mathrm{O} 3$ & \\
4 & $\mathrm{AA} 6061+15 \% \mathrm{Al}_{2} \mathrm{O}_{3}$ & $15 \mathrm{Al} \mathrm{O} 3$ & \\
5 & $\mathrm{AA} 6061+20 \% \mathrm{Al}_{2} \mathrm{O}_{3}$ & $20 \mathrm{Al} 2 \mathrm{O} 3$ & \\
6 & $\mathrm{AA} 6061+10 \% \mathrm{SiC}$ & $10 \mathrm{SiC}$ & \\
7 & $\mathrm{AA} 6061+15 \% \mathrm{SiC}$ & $15 \mathrm{SiC}$ & \\
8 & $\mathrm{AA} 6061+20 \% \mathrm{SiC}$ & $20 \mathrm{SiC}$ & \\
9 & $\mathrm{AA} 6061+10 \% \mathrm{AlN}$ & $10 \mathrm{AlN}$ & \\
10 & $\mathrm{AA} 6061+15 \% \mathrm{AIN}$ & $15 \mathrm{AIN}$ & \\
11 & $\mathrm{AA} 6061+20 \% \mathrm{AIN}$ & $20 \mathrm{AlN}$ & \\
12 & $\mathrm{AA} 6061+10 \% \mathrm{Si}_{3} \mathrm{~N}_{4}$ & $10 \mathrm{Si} 3 \mathrm{~N} 4$ & \\
13 & $\mathrm{AA} 6061+15 \% \mathrm{Si}_{3} \mathrm{~N}_{4}$ & $15 \mathrm{Si} 3 \mathrm{~N} 4$ & \\
14 & $\mathrm{AA} 6061+20 \% \mathrm{Si}_{3} \mathrm{~N}_{4}$ & $20 \mathrm{Si3N} 4$ & \\
\hline
\end{tabular}

A. High energy ball milling (HEBM): HEBM was performed in a Spex type vibrating mil, with 2 hours of duration. A ball powder to ratio of 10:1 was used. It was performed a wet milling, using isopropyl alcohol as PCA. After milling the powders were dried in an oven at a temperature of $100^{\circ} \mathrm{C}$.

B. X-ray diffraction (XRD): XRD tests were performed on SHIMADZU MAXIMA XRD-7000 equipment. The following test parameters were used:

- Diffraction angle: $\theta-2 \theta$;

- Scan range: $25^{\circ}-120^{\circ}$;

- Scan mode: continuous scanning;

- Scan speed: $1 \% \mathrm{~min}$;

- Step: $0,01^{\circ}$.

C. Granulometry: It was used the laser diffraction technique in liquid medium, using water as dispersant. The equipment used was the MALVERN INSTRUMENTES U.K. MASTERSIZER 2000.

D. Compactation and extrusion: The powders were uniaxial cold precompacted in a hydraulic press. A compaction pressure of 10 ton $/ \mathrm{cm}^{2}$ was used during 10 minutes. The extrusion was done at a temperature of $500{ }^{\circ} \mathrm{C}$, a progressive extrusion pressure and a feed rate of $2 \mathrm{~mm} / \mathrm{s}$ were applied (De Araujo Filho, 2017). Figure 1 shows composites before and after extrusion.

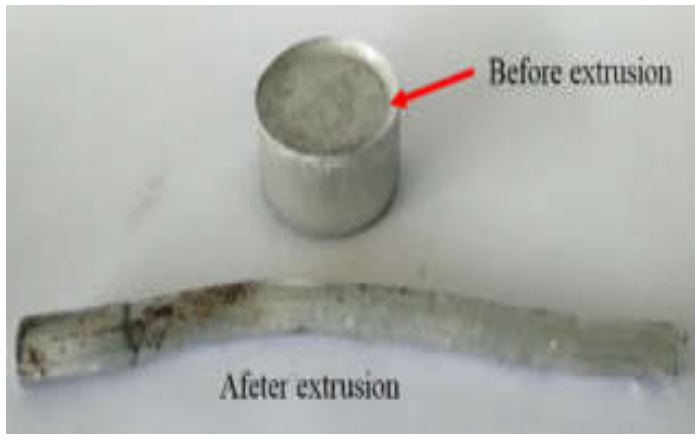

Figure 1 - Composite before and after extrusion

E. Samples preparation: The extrudates were cut into two sections: transverse (perpendicular to the extrusion direction) and longitudinal (parallel to the extrusion direction), Figure 2. The extrudeds were cutted on a STRUERS ACCUTOM-100 precision cutter. The sections were hardware in self-curing acrylic resin, sanded, polished and etched with a $0.5 \%$ hydrofluoric acid (HF) solution for 10 seconds.

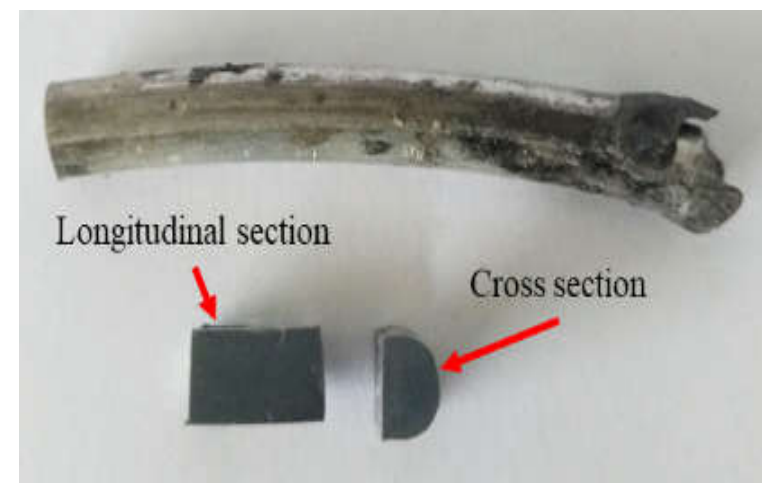

Figure 2 - Longitudinal and cross section of the extruded composites

F. Scanning electron microscopy (SEM): SEM and energy dispersive spectroscopy (EDS) were performed on the TESCAN MIRA3 microscope.

G. Microhardness Vickers: A load of $0.2 \mathrm{kgf}$ was applied for 15 seconds. The tests were performed on an EMCOTEST DURASCAN 700 durometer. 


\section{RESULTS AND DISCUSSION}

A. X-ray diffraction (XRD): In the AA6061 XRD results, Figure 3, the aluminum and $\mathrm{Mg}_{2} \mathrm{Si}$ peaks (Barbosa, 2014; Maisonnette, 2011) were identified. The aluminum and $\mathrm{Mg}_{2} \mathrm{Si}$ peaks were also identified in the composites, Figures 4 and 5.

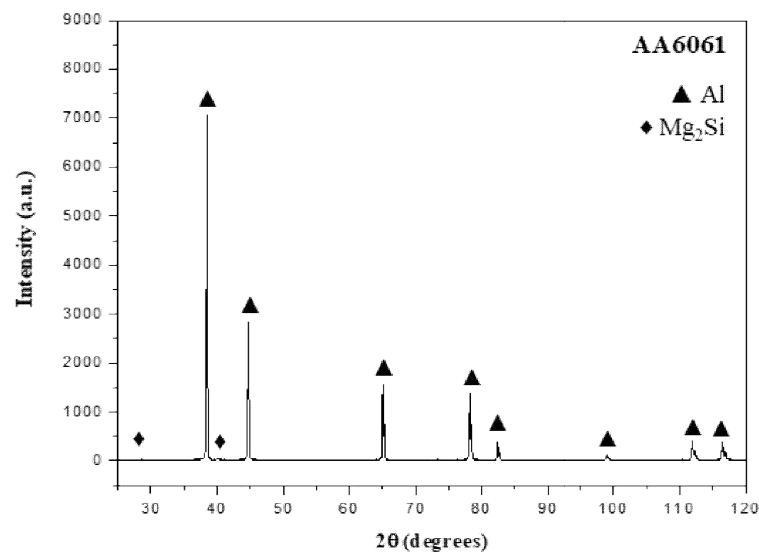

Figure 3 - X-ray diffraction patterns of AA6061 alloy
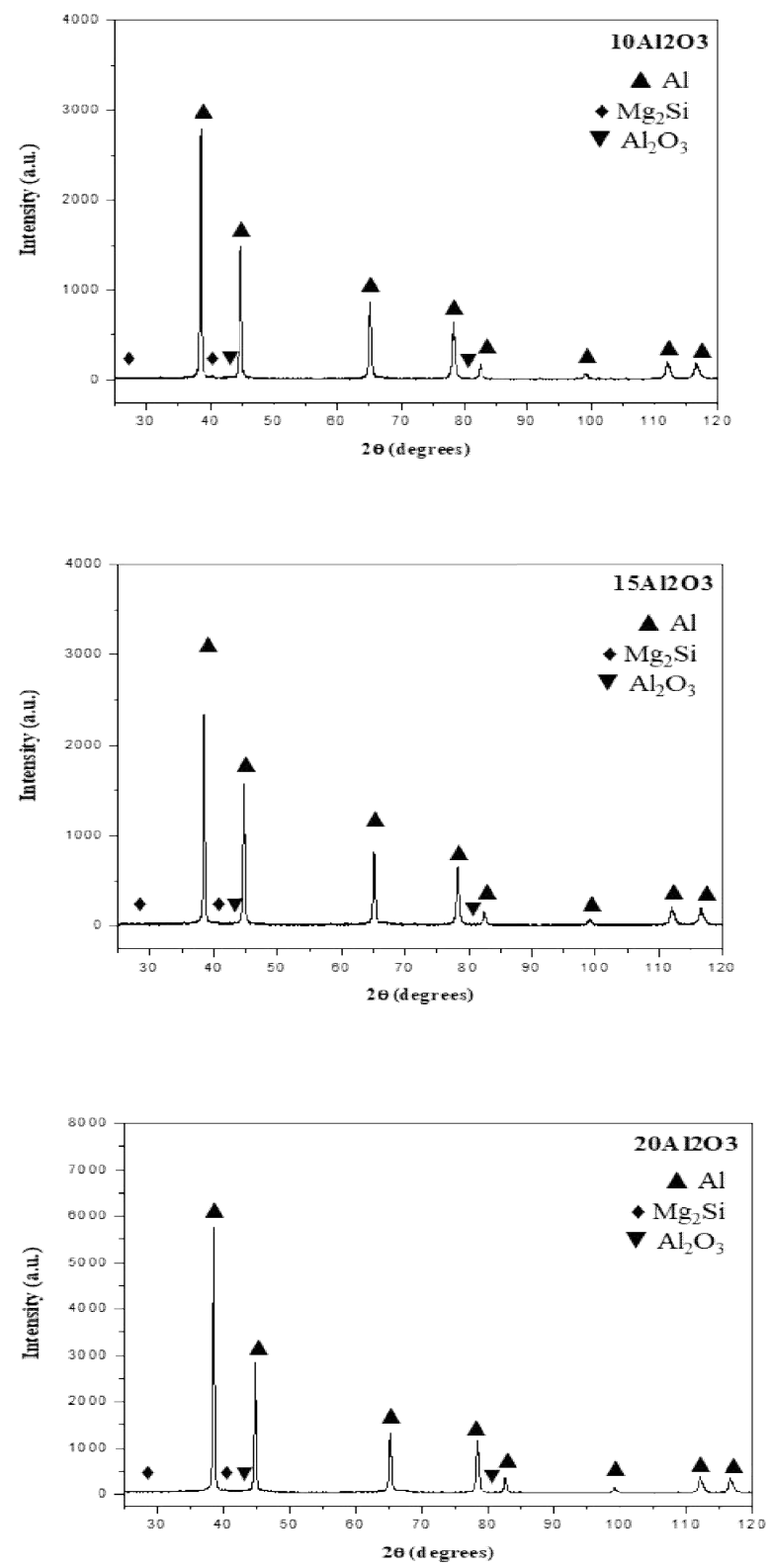

Two alumina peaks were identified, in the $\mathrm{Al}_{2} \mathrm{O}_{3}$ reinforced samples (Figure 4), the first peak presented at a $2 \theta$ angle of $43.34^{\circ}$ and the second at $82.104^{\circ}$. With the increase of alumina concentration in the composition there was no appreciable change in the results. Alumina peaks are smaller compared to aluminum peaks because alumina has been well incorporated into AA6061 alloy and there is also a tendency for alumina to form a thin film on the surface of aluminum powder particles (Araujo Filho, 2016; Fagagnolo, 2003). In SiC reinforced composites, Figure 4, it was possible to observe the evolution of the addition of the reinforcement phase in the aluminum matrix. In the $10 \mathrm{SiC}$ powder smaller and less intense peaks were observed, but with the increase of the reinforcement concentration to $15 \%$ and $20 \%$, an increase in the amount of SiC corresponding peaks was observed (ElDaly, 2012). It's still possible to say that the high energy milling was efficient with regard to the incorporation of the reinforcement into the matrix. Since the reinforcement phase peaks were low intensity peaks compared to the higher energy peaks for aluminum (Abdoli, 2008). The AlN-reinforced samples, Figure 5, showed similar behavior to the SiC-reinforced samples. However, in the 20AIN sample, the presence of magnesium silicate $\left(\mathrm{Mg}_{2} \mathrm{SiO}_{4}\right)$ was detected due to the presence of oxygen at the moment of HEBM causing the oxidation of $\mathrm{Mg}_{2} \mathrm{Si}$. In addition to $\mathrm{Mg}_{2} \mathrm{SiO}_{4}$, iron carbide $\left(\mathrm{Fe}_{7} \mathrm{C}_{3}\right)$ was identified, since there is no carbon in the composition of any of the main composite components, this carbide was formed due to the presence of stearic acid in the milling of powders, favoring carbide formation (ElEskandarany, 2001).
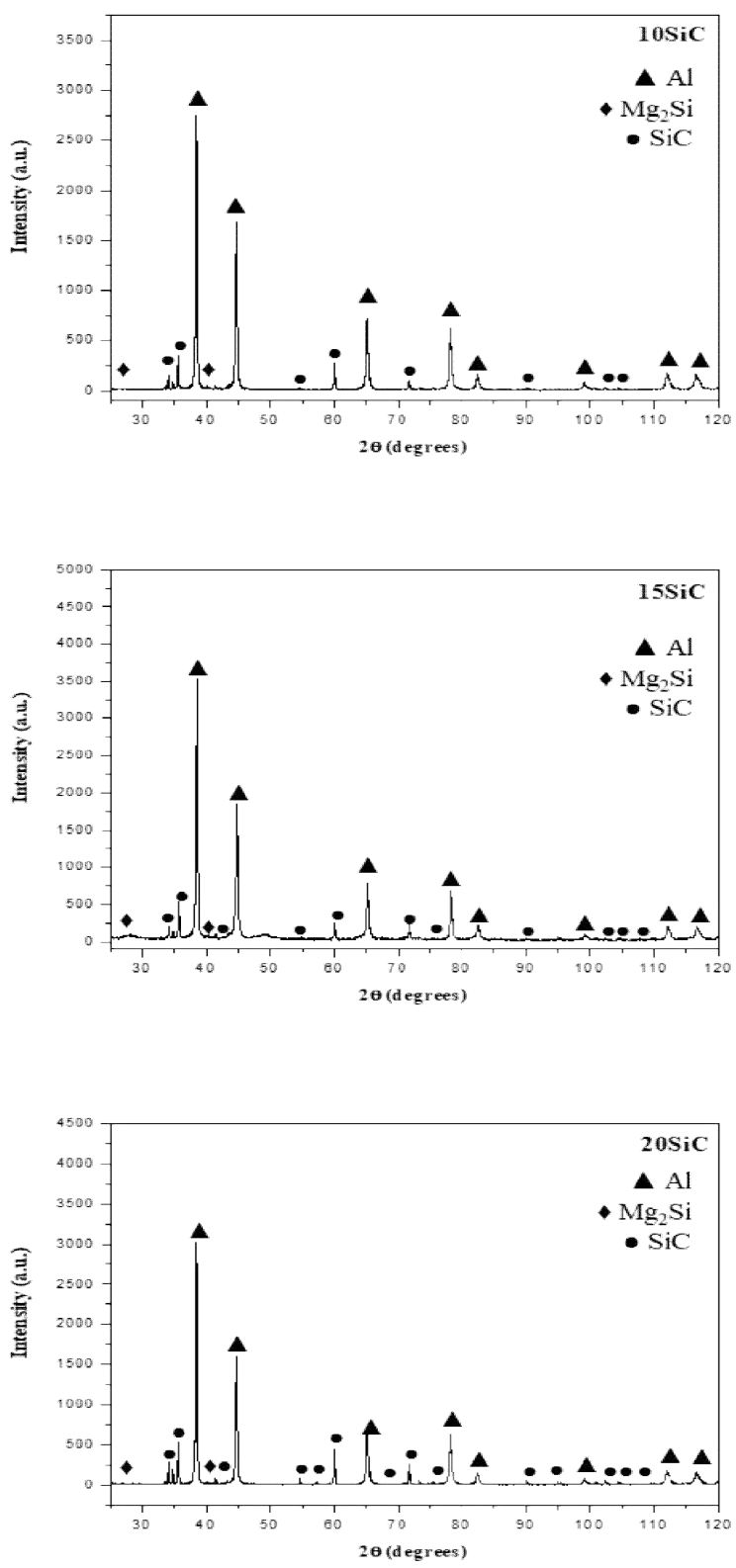

Figure 4 - X-ray diffraction patterns of $\mathrm{Al}_{2} \mathrm{O}_{3}$ and $\mathrm{SiC}$ reinforced composites 

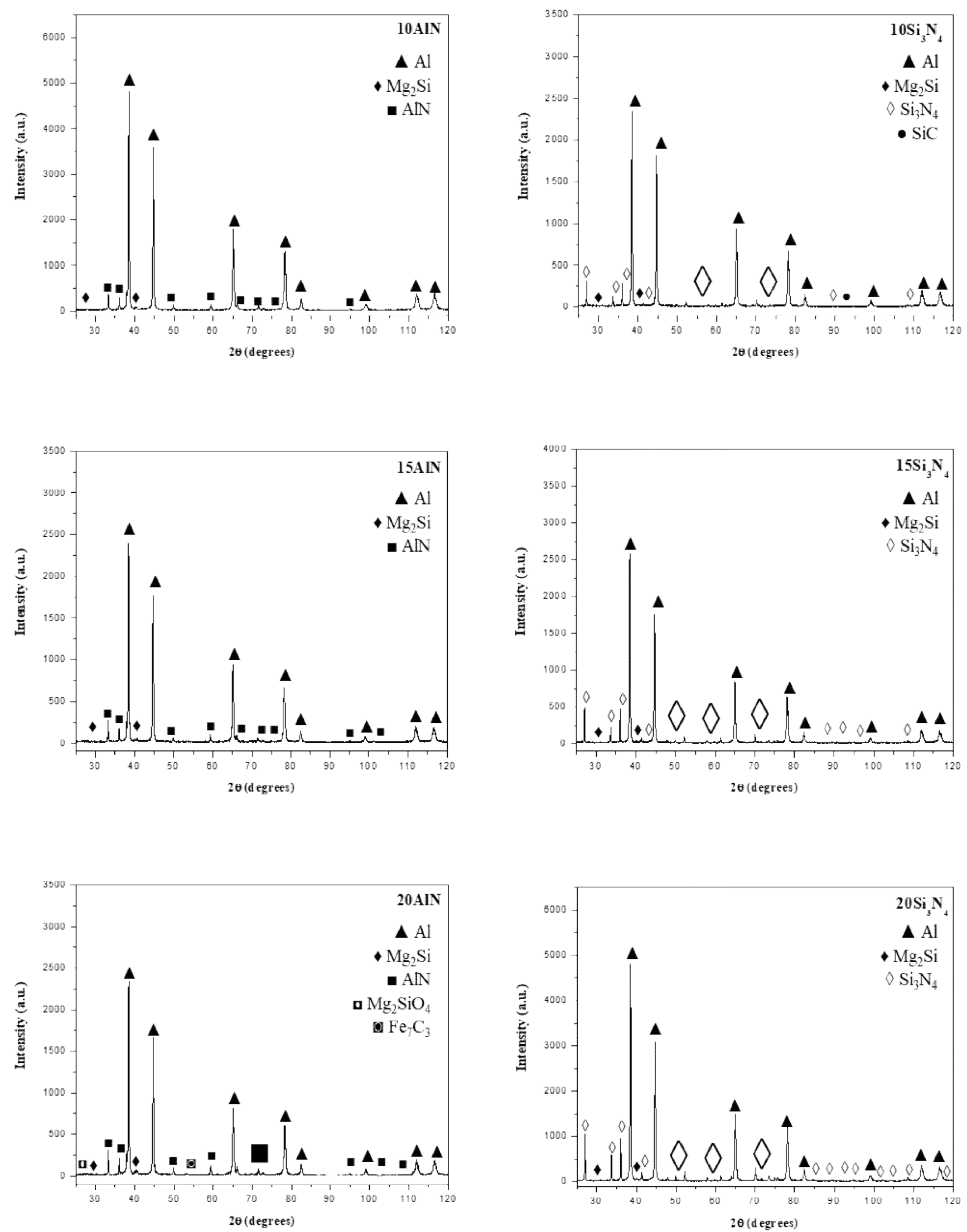

Figure 5 - X-ray diffraction patterns of $\mathrm{AIN}$ and $\mathrm{Si}_{3} \mathrm{~N}_{4}$ reinforced composites

In $\mathrm{Si}_{3} \mathrm{~N}_{4}$ reinforced samples, Figure 5 , there was a $\mathrm{SiC}$ formation in the 10Si3N4 sample due to the carbide formation tendency promoted by the presence of stearic acid. In the $15 \mathrm{Si} 3 \mathrm{~N} 4$ and $20 \mathrm{Si} 3 \mathrm{~N} 4$ samples there was only the presence of the aluminum, $\mathrm{Mg}_{2} \mathrm{Si}$ and $\mathrm{Si}_{3} \mathrm{~N}_{4}$ peaks.

B. Granulometry: The particle size distribution curves of the powders, Figure 6 , have a monomodal shape, so it was found that the
HEBM was satisfactory (Upadhyaya, 2002). From the unreinforced AA6061 alloy curves it was observed that the AA0's powder has a symmetrical curve. However, the AA2's powder showed an asymmetric distribution with a slight tendency towards the largest particle size region, this fact occurs when the phase of cold welding of the powder particles during the HEBM occurs more strongly (Fagagnolo, 2003). The same is true for reinforced powders, especially 


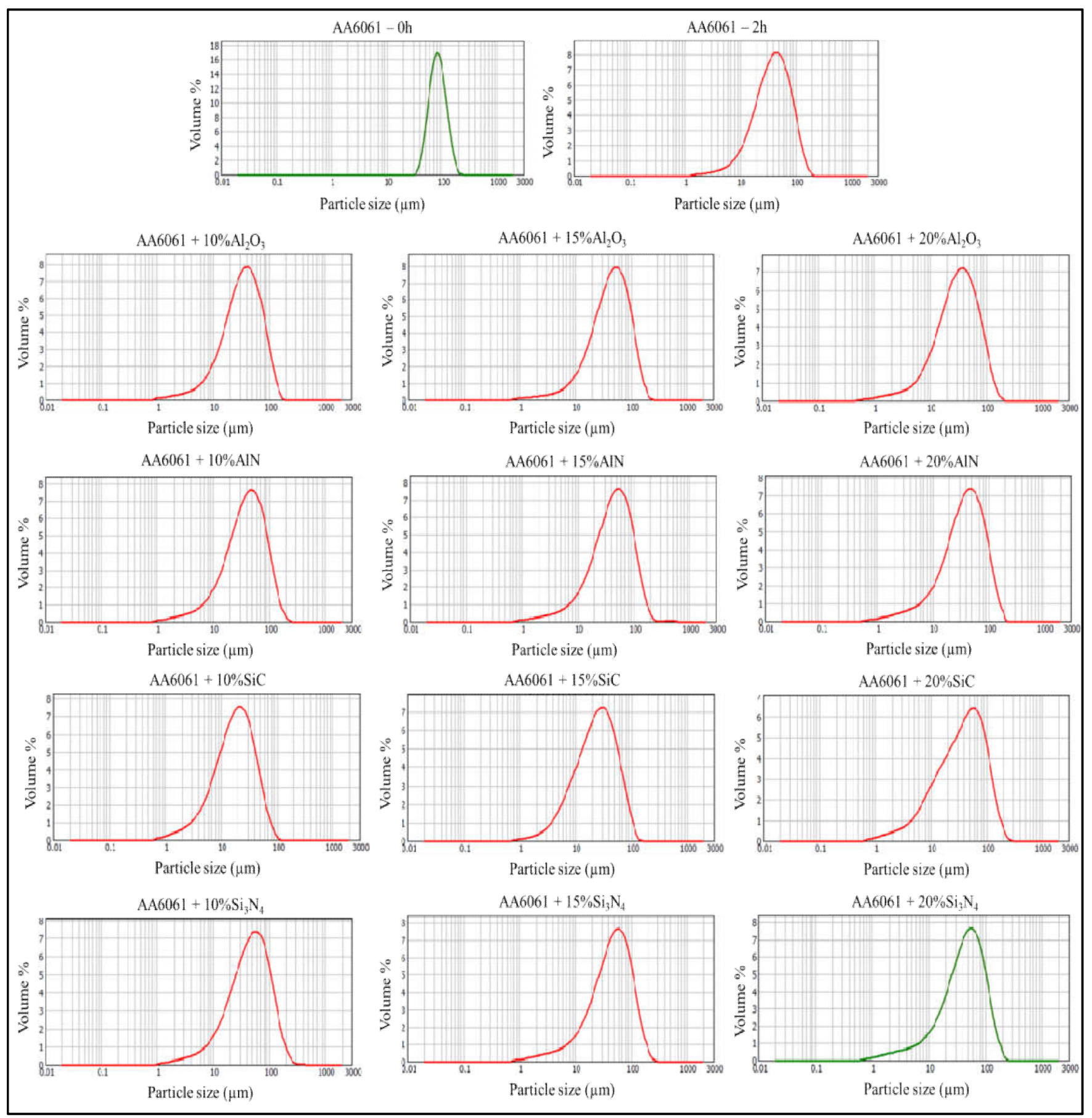

Figure 6. Particle size distribution

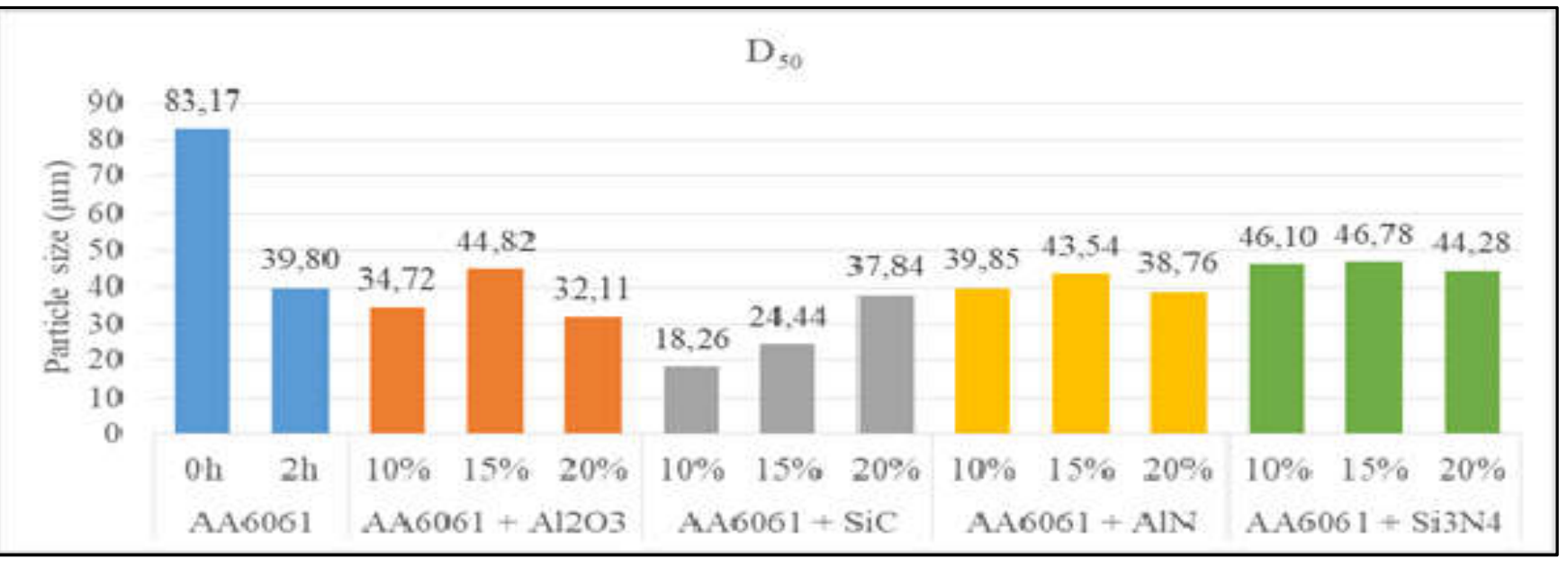




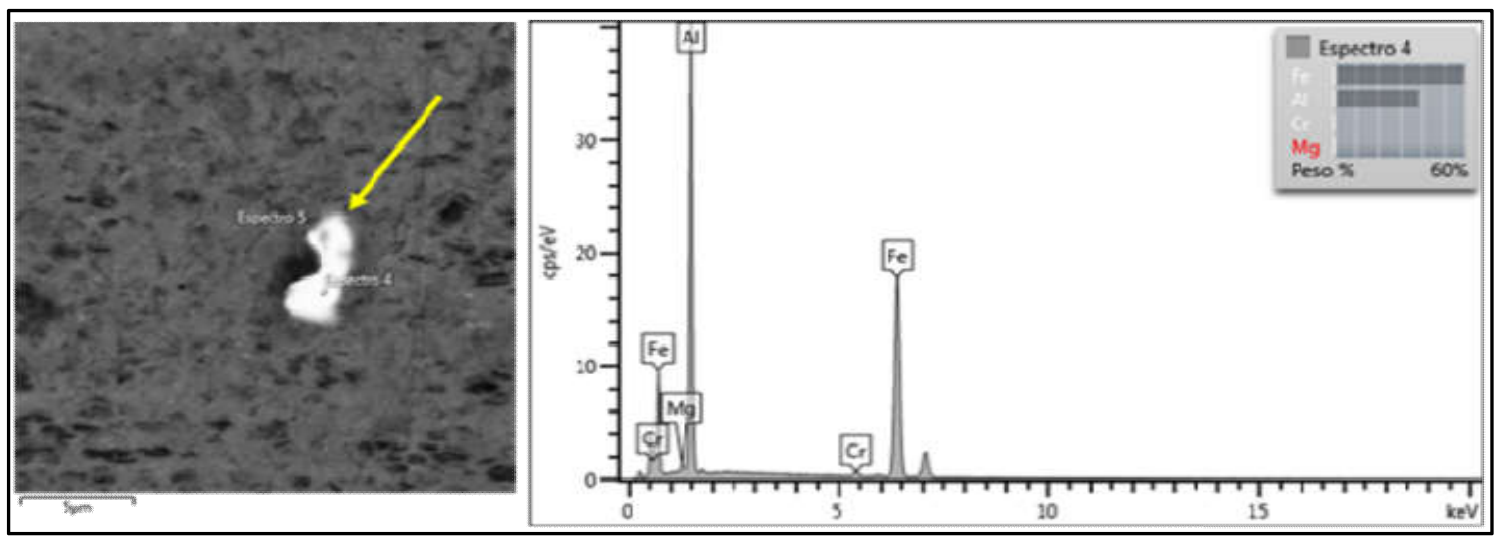

Figure 8. Impurity identification

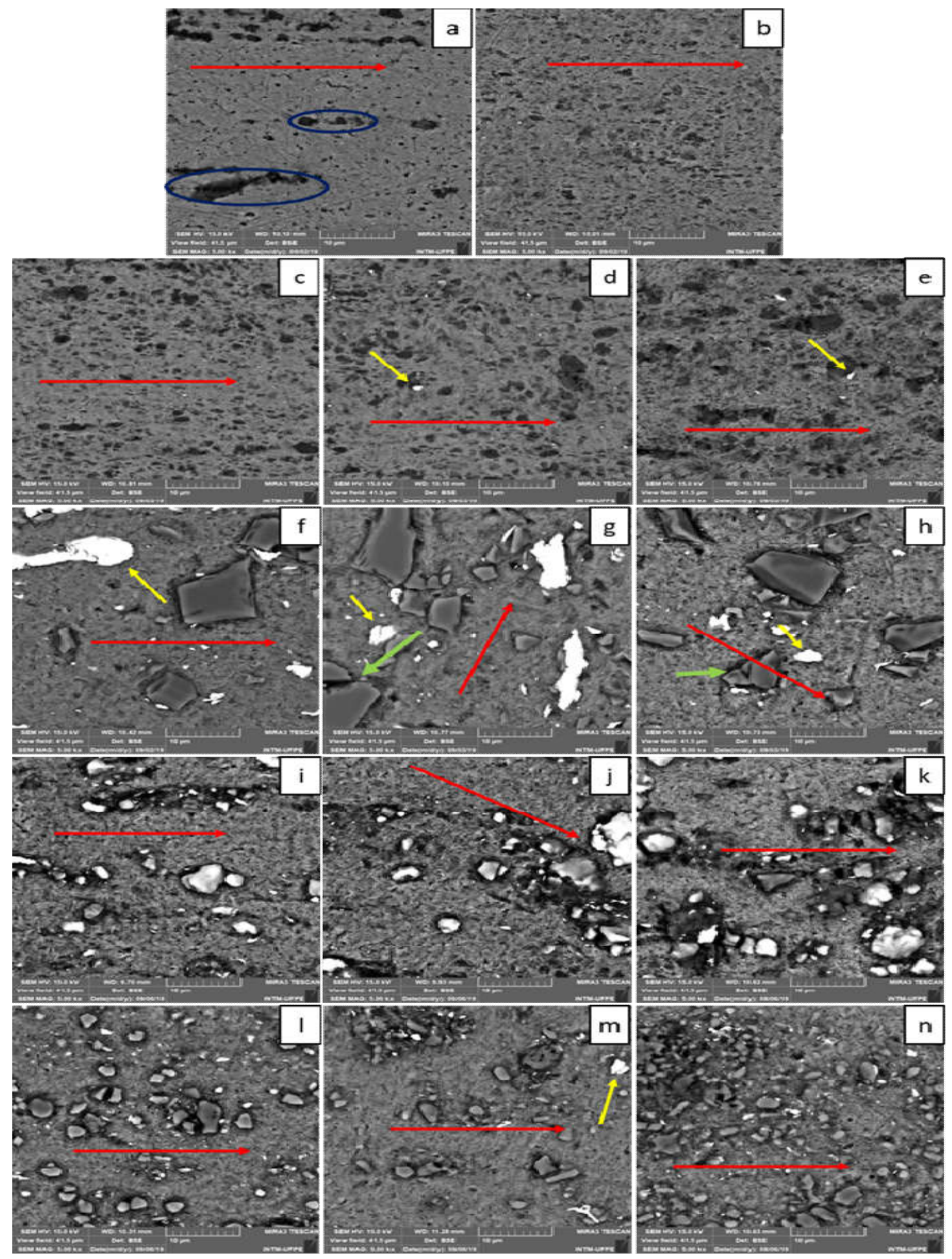

Figure 9. SEM images of extruded's longitudinal sections 
in the $15 \%$ reinforcement fraction. However, the sample with the strongest tendency for the region with the largest particle size was the 20SiC sample. The median particle sizes are shown in Figure 7 It was observed that AA0 powder has an average particle size of 83.17 $\mu \mathrm{m}$ whereas AA2 powder has a median particle size of $39.80 \mu \mathrm{m}$, ie HEBM caused a $52.15 \%$ reduction in the average particle size of the unreinforced alloy so HEBM causes powder refining (Suryanarayana, 2001). The increased amount of alumina in the aluminum matrix promotes a decrease in the particle size of the powder (Alizadeh, 2011), this fact occurs mainly in the $20 \mathrm{Al} 2 \mathrm{O} 3$ composition. In silicon carbide reinforced powders the highest refining rate is achieved in the 10SiC composition (Hassani, 2014). However as the reinforcement concentration in the matrix increased, larger median particle sizes were obtained. So the addition of reinforcement promotes an increase in cold welding rates in the early stages of HEBM (De Araujo Filho, 2017). Aluminum nitride reinforced powders behaved similarly to alumina reinforced powders. There was a more pronounced median particle size reduction in the 20AlN composition (Caballero, 2014). For the silicon nitride reinforced powders there was no major change in particle sizes for the three compositions, but even more refining in the 20Si3N4 composition was dyed (Fernandez, 2019). of the reinforcement in the matrix, however samples 15Al2O3, Figure 9.d, and 20A12O3, Figure 9.e, have a less homogeneous dispersion of the reinforcement. In SiC-reinforced samples there was a reduction in porosity, since the ratio between the matrix powder particle size and the reinforcement powder size approaches the unity occurs a better dispersion of the reinforcement phase in the matrix and the number of pores is reduced (Sun, 2010). As can be seen from the micrographs, Figure 9.f-h, the pores coexist in the bonding region between the matrix and the reinforcement particles. These pores cause a discontinuity in the bond between the reinforcing particles and the matrix, thereby degrading the mechanical properties of the material. In composites $15 \mathrm{SiC}$, Figure 9.g, and $20 \mathrm{SiC}$, Figure 9.h, it was observed that some reinforcement particles fractured after extrusion (indicated by the green arrows), this is due to the high shear forces existing during extrusion (Adamiak, 2004). In the AlN reinforced samples, Figure 9.i-k, the reinforcement tended to form agglomerates in the bonding region between the particles of the matrix powder. This trend causes a degradation of the mechanical properties of the material as it creates zones with no continuity between the matrix and the reinforcement. A large amount of pores have been identified in the samples.

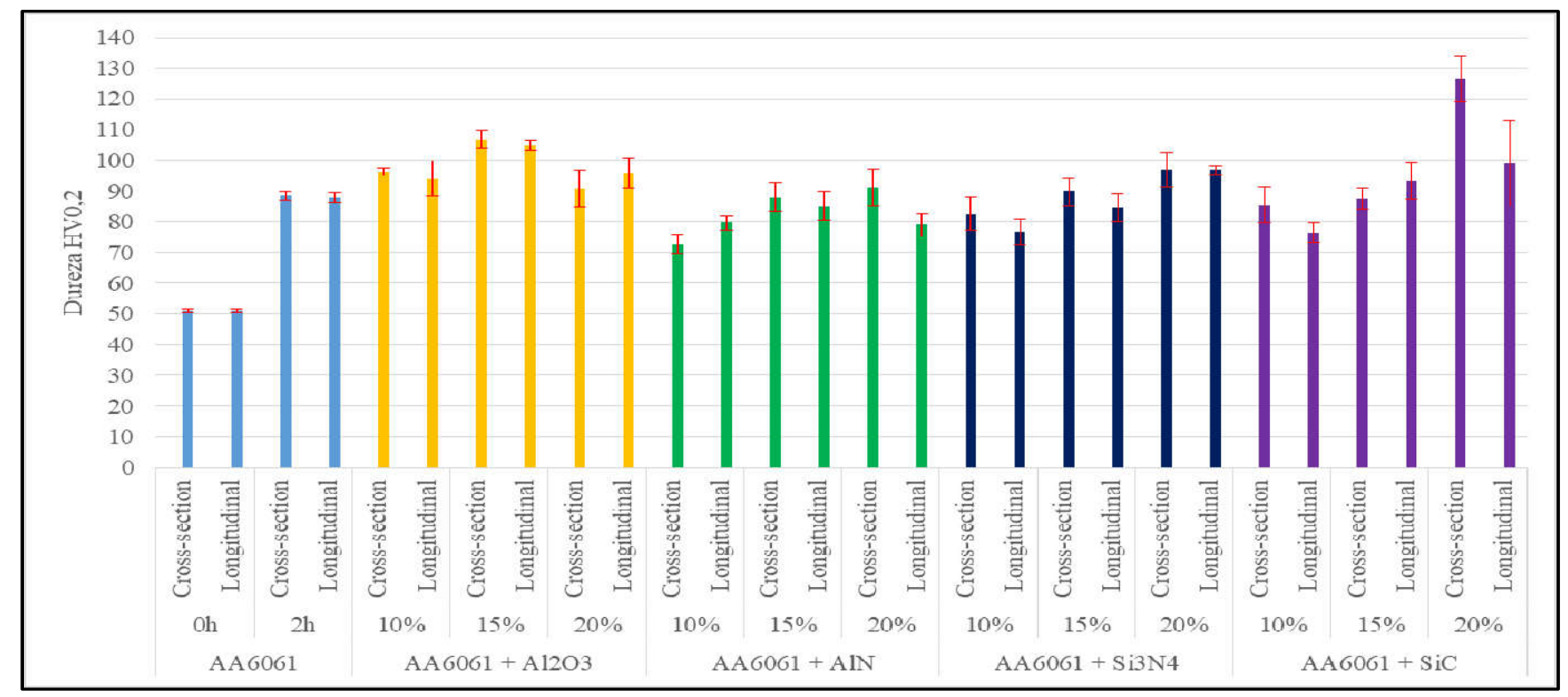

Figure 10. HV hardness evolution of the composites as a function of the amount of reinforcement

C. Scanning electron microscopy (SEM): With the microstructural characterization of the extrudates, it was possible to observe the presence of white colored particles in all the samples, highlighted by the yellow arrows (Figures 8 and 9). A spot EDS was then performed on these particulates, Figure 8 , and it was identified that these are stainless steel particles from the wear of the jar and grinding balls. Figure 9 shows the micrographs of the extruded longitudinal sections. Sample AA0 even after extrusion became very porous (pores highlighted with the blue circle - Figure 9.a). Other authors have found an almost total reduction in porosity after extrusion (Jin, 2011), the powder used to make the AA0 sample did not go through high energy grinding and also the oxide surface layer makes it difficult to join the powder particles. The micrographs of sample AA2, Figure 9.b, showed a reduction in porosity compared to sample AA0. The remaining porosity is due to particle morphology as laminar particles do not have good packing (Fagagnolo, 2003). In the samples reinforced with $\mathrm{Al}_{2} \mathrm{O}_{3}$ it was observed that with the increase of the reinforcement content there is an increase of the alumina accumulation in the sample structure. Alumina tends to form agglomerates in the joining zone between particles, which may cause degradation of the mechanical properties of the material. Porosity was still identified in the samples, but with alumina filling most of the existing pores (Reddy, 2017). It was identified that with the increase of the reinforcement content its dispersion in the matrix was less homogeneous. Sample 10Al2O3, Figure 9.c, have a good dispersion
This is due to the ratio between the reinforcement particle size and the matrix powder particle size. When this ratio distances of the unity, a segregated structure is formed (Subramanian, 2015) ie with little cohesion between the particles. Resulting in a more porous and less resistant structure. The $\mathrm{Si}_{3} \mathrm{~N}_{4}$-reinforced samples, Figure 9.1-n, had some reinforcement agglomerates, but in smaller quantities than the AlN-reinforced samples. Since the reinforcement is better dispersed in the matrix, the porosity also tends to decrease. Although porosity coexists with the reinforcing particles in the binding region between reinforcement and matrix. Due to the shear forces present in the extrusion process, the reinforcement tends to align in a direction parallel to the extrusion direction (Jin, 2011). This fact can be observed in Figure 9 where the extrusion direction is indicated by the red arrows.

D. Microhardness Vickers: The hardness of sample AA2 was higher than that of AA0, Figure 10. This behavior can be explained because when performing HEBM the powder particles are cold deformed causing an increase in dislocations density in the powders particles, so they suffer mechanical hardening (De Araujo Filho, 2017; Jin, 2011; Sun, 2010; Adamiak, 2004). Therefore, HEBM processing followed by hot extrusion is capable to achieve a similar hardness to a heattreated cast alloy and has higher hardness than sintered material. The addition of alumina together with the HEBM process contributed to increase the hardness of the composites (Araujo Filho, 2016), 
reaching a maximum hardness of $106,80 \mathrm{HV}$ (cross section) and $104,80 \mathrm{HV}$ (longitudinal section) in the $15 \mathrm{Al} 2 \mathrm{O} 3$ composite. There was a reduction in hardness in the $20 \mathrm{Al} 2 \mathrm{O} 3$ sample, as it presented the largest reinforcement agglomerates in the matrix. The agglomeration of alumina in the bonding region of the powder particles causes the degradation of mechanical properties (Subramanian, 2015). Cast alloys reinforced with $10 \%$ of alumina reached $\sim 100 \mathrm{HV}$ (Singla, 2015). Extruded aluminum alloys reinforced with alumina showed increased hardness with increasing reinforcement content, with the highest hardness being in the composite with 15\% alumina addition (Reddy, 2017). Aluminareinforced extruded aluminum alloys, being processed for 5 hours by HEBM, reached hardness exceeding $130 \mathrm{HV}$ for $20 \%$ alumina (Alizadeh, 2011). Thus it was observed how much the milling time interferes with the final hardness of the material. The composites reinforced with $10 \%$ and $15 \% \mathrm{SiC}$ showed no significant increase in hardness, however the $20 \mathrm{SiC}$ sample showed a considerable increase in hardness, being the hardest compound. The insertion of silicon carbide causes an increase in hardness (Araujo Filho, 2016; De Araujo Filho, 2017; El-Daly, 2012; Umasankar, 2014). This increase in hardness causes the composite to become more brittle, decreasing its ductility (Zhao, 1991). Other authors also obtained similar results in their research: a hardness of $88.1 \mathrm{HV} 0.5$ was achieved for a $10 \% \mathrm{SiC}$ composite and $101.9 \mathrm{HV} 0.5$ for a $15 \% \mathrm{SiC}$ composition (Knowles, 2014); hardness increases with decreasing particle size (Sun, 2010), ie for longer HEBM times more refined is the powders and therefore harder composites are obtained. In 10AIN and 15AlN samples the addition of reinforcement was ineffective as they had a lower hardness than the AA2 sample. 20Aln sample was the only composition that had na increase in hardness relative to unreinforced alloys, even though the increase in hardness was small. The addition of aluminum nitride was ineffective because there was large reinforcement's agglomeration in the sample body, causing the degradation of mechanical properties (Subramanian, 2015). $\mathrm{Si}_{3} \mathrm{~N}_{4}$ reinforced composites obtained good homogeneity of the hardness property in the sample, since the hardness of the cross (max. 96,96HV) and longitudinal $(96,80 \mathrm{HV})$ sections are similar, similar behavior to the alumina reinforced samples. This happens because the near uniform dispersion of the reinforcement in the matrix.

This reinforcement also showed increased hardness as its amount in the matrix was increased. In cast aluminum alloys reinforced with aluminum nitride an average hardness of $78.5 \mathrm{HV}$ was obtained (Ambigai, 2017). Increasing the reinforcement content in the matrix causes an increase in hardness (Zhang, 2019) as well an increase of the yield strength of composites (Parveen, 2019). The $\mathrm{Mg}_{2} \mathrm{Si}$ phase was identified in the samples and the reinforcement was well incorporated into the aluminum alloy matrix. Carbides and oxides occurred in some samples due to the insertion of stearic acid as the PCA and because the HEBM was made under an uncontrolled atmosphere. Reinforcement insertion into the matrix accelerated the HEBM process and the milling process was successful as the particle size distribution curve was monomodal. HEBM followed by hot extrusion causes an increase in hardness of the material. The samples that did not show reinforcement agglomerates in their structure had a more homogeneous hardness along the material body, samples reinforced with $\mathrm{Al}_{2} \mathrm{O}_{3}$ and $\mathrm{Si}_{3} \mathrm{~N}_{4}$. The samples that presented AIN agglomerates had their properties compromised. The insertion of reinforcement in the matrix caused an increase in material hardness, with the hardest composite being $20 \mathrm{SiC}$.

\section{CONCLUSION}

The $\mathrm{Mg}_{2} \mathrm{Si}$ phase was identified in the samples and the reinforcement was well incorporated into the aluminum alloy matrix. Carbides and oxides occurred in some samples due to the insertion of stearic acid as the PCA and because the HEBM was made under an uncontrolled atmosphere. Reinforcement insertion into the matrix accelerated the HEBM process and the milling process was successful as the particle size distribution curve was monomodal. HEBM followed by hot extrusion causes an increase in hardness of the material. The samples that did not show reinforcement agglomerates in their structure had a more homogeneous hardness along the material body, samples reinforced with $\mathrm{Al}_{2} \mathrm{O}_{3}$ and $\mathrm{Si}_{3} \mathrm{~N}_{4}$. The samples that presented AlN agglomerates had their properties compromised. The insertion of reinforcement in the matrix caused an increase in material hardness, with the hardest composite being $20 \mathrm{SiC}$.

\section{ACKNOWLEDGMENT}

The authors wish to thank the Federal University of Pernambuco (UFPE), Mechanical Engineering Department, Graduate Program in Mechanical Engineering (GPME), CNPq, CAPES and FACEPE.

\section{REFERENCES}

Abdoli H., Salahi E., Farnoush, H., Pourazrang, K.(2008)Evolutions during synthesis of Al-AlN-nanostructured composite powder by mechanical alloying. In J Alloys Compd, 461, pp.166-172.

Adamiak, M., Fagagnolo J. B., Ruiz-Navas E. M. Dobrazañski L. A., Torralba J. M.(2004)Mechanically milled AA6061/(Ti $\left.{ }_{3} \mathrm{Al}\right)_{\mathrm{P}}$ MMC reinforced with intermetallics - the structure and properties. In J Mater Process Technol, 155-156, pp.2002-2006.

Alizadeh M., Aliabadi M. M. (2011) Synthesis behavior of nanocrystalline $\mathrm{Al}-\mathrm{Al}_{2} \mathrm{O}_{3}$ composite during low time mechanical milling process. In J Alloys Compd, 509, pp.4978-4986.

Ambigai R., Prabhu S. (2017) Optimization of friction and wear behaviour of $\mathrm{Al}-\mathrm{Si}_{3} \mathrm{~N}_{4}$ nano composite and $\mathrm{Al}-\mathrm{Gr}-\mathrm{Si}_{3} \mathrm{~N}_{4}$ hybrid composite under dry sliding conditions. In Trans Nonferrous Met Soc China, 27(5), pp.986-997.

Araujo Filho O. O., De Moura A. D. A., De Araújo E. R., Dos Santos M. J., Gonzalez C. H., Da Silva F. J.(2016) Manufacturing and Characterization of AA1100 Aluminum Alloy Metal Matrix Composites Reinforced by Silicon Carbide and Alumina Processed by Powder Metallurgy. In Mater Sci Forum, 869, pp. 447-451.

Baldacim S. A.(2000) Desenvolvimento, processamento e caracterização de compósitos cerâmicos Si3N4-SiC(w). Ph. D. Thesis in Science of Nuclear Technology-Materials. Instituto de Pesquisas Energéticas e Nucleares (IPEN), University of São Paulo, São Paulo (SP) Brazil.

Barbosa C.(2014) Metais não ferrosos e suas ligas: Microestrutura, propriedades e aplicações. 1st ed., E-papers, Rio de Janeiro, Brazil.

Budumuru S., Anuradha M. S. (2021) Analysis of electromagnetic shielding effectiveness properties of Al6061 metal matrix composites at $\mathrm{X}$-band for aerospace applications. In Microeletron, Electromagn and Telecommun, 655, pp. 467-476.

Caballero E. S., Cintas J., Cuevas F. G., Montes J. M., Ternero F., Reina F. J. V.(2017) Synthesis and characterization of in situreinforced $\mathrm{Al}-\mathrm{AlN}$ composites produced by mechanical alloying. In J Alloys Compd, 728, pp.640-644.

Callister W. D. Jr., Rethwisch D. G. (2010) Materials Science and Engineering: an Introduction. 8th ed.,Jhon Wiley \& Sons, USA.

Campos H. G. (2016) Propriedades mecânicas de compósito à base de alumina e zircônia com adição de céria. Master Dissertation in Mining, Metallurgy and Materials Engineering. Federal University of Rio Grande do Sul, Porto Alegre (RS) Brazil.

Da Silva M. V., Stainer D., Al-Qureshi H. Á., Hotza D. (2014) Blindagens cerâmicas para aplicações balísticas: uma revisão.In Cerâmica, 60, pp. 323-331.

De Araujo Filho O. O., De Araújo E. R., De Lira H. M., Gonzalez C. H., Silva N. D. G., Urtiga Filho S. L.(2017) Manufacturing of AA2124 Aluminum Alloy Metal Matrix Composites Reinforced by Silicon Carbide Processed by Powder Metallurgy Techniques of High Energy Ball Milling and Hot Extrusion. In Mater Sci Forum, 899, pp. 25-30.

El-Daly A. A., Abdelhameed M., Hashish M., Eid A. M. (2012) Synthesis of $\mathrm{Al} / \mathrm{SiC}$ nanocomposite and evaluation of its mechanical properties using pulse echo overlap method. In J Alloys Compd, 542, pp.51-58. 
El-Eskandarany M. S. (2001) Mechanical Alloying for Fabrication of Advanced Engineering Materials. Vol. 1, Noyes Publications, New York, USA.

Fagagnolo J. B., Velasco F., Robert M. H., Torralba J. M.,(2003) Effect of mechanical alloying on the morphology, microstructure and properties of aluminium matrix composite powders. In Mater Sci Eng, A 342, pp. 131-143.

Fernandez H., Ordoñez S., Pesenti H., González R. E., Leoni M. (2019) Microstructure homogeneity of milled aluminum A356$\mathrm{Si}_{3} \mathrm{~N}_{4}$ metal matrix composite powders. In J Mater Res Technol, 8(3), pp. 2969-2977.

Hassani A., Bagherpour E., Qods F. (2014).Influence of pores on workability of porous $\mathrm{Al} / \mathrm{SiC}$ composites fabricated through powder metallurgy+mechanical alloying. In J Alloys Compd, 591, pp.132-142.

Jin P., Xiao B., Wang Q., Ma Z., Liu Y., Li S. (2011) Effect of hot extrusion on interfacial microstructure and tensile properties of $\mathrm{SiC}_{\mathrm{p}} / 2009 \mathrm{Al}$ composites fabricated at diferente hot pressing temperatures. In J Mater Sci Technol, 27(6), pp.518-524.

Knowles A. J., Jiang X., Galano M., Audebert F. (2014) Microstructure and mechanical properties of $6061 \mathrm{Al}$ alloy based composites with $\mathrm{SiC}$ nanoparticles. In J Alloys Compd, 615, pp. 401-405.

Kumar M., Murugan A. M. (2017) Tribological characterization of Al6061/alumina/graphite/redmud hybrid composite for brake rotor application. In Part ScieTechnol, 37, pp. 261-274.

Kumar N. M., Kumaraswamidhas L. A. (2018) Characterization and tribological analysis on AA6061 reinforced with AlN and ZrB2 in situ composites. In J Mater Res Technol, 8(3), pp. 969-980.

Maisonnette D., Suery M., Nelias D., Chaudet P., Epicier T. (2011) Effects of heat treatments on the microstructure and mechanical properties of a 6061 aluminium alloy. In Mater Sci Eng, 528, pp. 2718-2724.

Parveen A., Chauhan N. R., Suhaib M. (2019) Study of $\mathrm{Si}_{3} \mathrm{~N}_{4}$ reinforcement on the morphological and tribo-mechanical behaviour of aluminium matrix composites. In Mater Res Express, 6(4), pp.042001-042019.
Reddy M. P., Ubaid F., Shakoor R. A., Parande G., Manakari V., Mohamed A. M. A., Gupta M. (2017) Effect of reinforcement concentration on the properties of hot extruded $\mathrm{Al}^{-} \mathrm{Al}_{2} \mathrm{O}_{3}$ composites synthesized through microwave sintering process. In Mater SciEng, A 696, pp. 60-69.

Singla Y. K.., Chhibber R., Bansal H., Kalra A. (2015) Wear Behavior of Aluminum Alloy 6061-Based Composites Reinforced with $\mathrm{SiC}, \mathrm{Al}_{2} \mathrm{O}_{3}$, and Red Mud: A Comparative Study. In Jom, 67(9), pp. 2160-2169.

Subramanian J., Seetharaman S., Gupta M. (2015) Processing and Properties of Aluminum and Magnesium Based Composites Containing Amorphous Reinforcement: A Review. In Metals, 5, pp. 743-762.

Sun C., Song M., Wang Z., He Y. (2010) Effect of Particle Size on the Microstructures and Mechanical Properties of SiC-Reinforced Pure Aluminum Composites. In J Mater Eng Perform, 20(9), pp.1606-1612.

Suryanarayana C. (2001) Mechanical alloying and milling. In Prog Mater Sci, 46, pp.1-184.

Umasankar V., Xavior M. A., Karthikeyan S. (2014) Experimental evaluation of the influence of processing parameters on the mechanical properties of $\mathrm{SiC}$ particle reinforced AA6061 aluminium alloy matrix composite by powder processing. In $\mathrm{J}$ Alloys Compd, 582, pp. 380-386.

Upadhyaya G. S.(2002) Powder Metallurgy Technology. Cambridge International Science Publishing, Cambridge.

Zhang C., Zeng Y., Yao D., Yin J., Zuo K., Xia Y., Liang H. (2019) The improved mechanical properties of $\mathrm{Al}$ matrix composites reinforced with oriented $\beta-\mathrm{Si}_{3} \mathrm{~N}_{4}$ whisker. In J MaterSci Technol, 35(7), pp. 1345-1353.

Zhao Z., Zhijan S., Yingkun X. (1991) Effect of microstructure on the mechanical properties of na Al alloy 6061-SiC particle composite. In Mater Sci Eng, A 132, pp. 83-88. 